\title{
POLICE BAIL WITHOUT CHARGE: THE HUMAN RIGHTS IMPLICATIONS
}

\author{
Ed CAPE AND Richard A. EdWARds*
}

\begin{abstract}
Whilst the power of the police to release a person on bail prior to trial has existed for centuries, the power to release on bail a person suspected of but not charged with a criminal offence has been available to the police only since 1925. The power to attach conditions to pre-charge bail is of very recent origin, having been introduced for the first time in 2003 but rapidly expanded since then. Whilst imposing restrictions on the liberty of a person should, constitutionally, be reserved to the judiciary, the fact that it was originally conceived, in part at least, as a mechanism for enhancing liberty reduced the constitutional tension created by allowing members of the executive such powers. However, the changing role of arrest in the investigation of crime and the granting of extensive powers to the police to impose bail conditions means that the police now have the ability to place controls on people not charged with a criminal offence for extended periods of time. It is argued here that this is in breach of the right to liberty under Article 5 of the European Convention on Human Rights and, in practice, may also breach other Convention rights.
\end{abstract}

Key words: Police bail, bail conditions, human rights, ECHR, Article 5

\section{INTRODUCTION}

OVER the past decade the powers of the police to subject a person, who has been arrested but not charged with a criminal offence, to bail with conditions attached have dramatically increased. Although statistics are not routinely collected, it is likely that thousands of people each year are subjected to conditions that may range from non-association with specified people, or not going to specified locations, to residing at a particular address and abiding by a curfew. Such conditions may be imposed for lengthy periods of time, and whilst the conditions themselves may be reviewed by a court, in practice the decision to "impose" bail cannot. It is worth emphasising from the outset that such conditional bail may be imposed on a person even though there is insufficient evidence to charge them with a criminal offence. All that is required is that the person has been arrested.

\footnotetext{
* Professor and Principal Lecturer in Law respectively, Department of Law, University of the West of England, Bristol. The authors wish to thank the reviewers for their perceptive comments and suggestions.
} 
Whilst these powers has occasionally caught the attention of the media, ${ }^{1}$ they have otherwise received very little attention. ${ }^{2}$ Although the powers pose a significant challenge to well entrenched constitutional and human rights, for the most part they have been considered only in terms of whether they serve the interests of efficient police investigation. When considering the introduction of powers to attach conditions to bail granted to a person immediately after their arrest (street bail), the Joint Parliamentary Committee on Human Rights concluded that they did not give rise to significant incompatibility with the European Convention on Human rights (ECHR). ${ }^{3}$ The few decisions of the courts on pre-charge police bail have either not considered or given short shrift to human rights concerns. ${ }^{4}$ The powers have similarly attracted little interest from the legal profession or academics. ${ }^{5}$

In view of the significance of the powers under scrutiny, we begin with a detailed account of police powers to grant bail, tracing their development from the introduction of "modern" policing in the nineteenth century to the present day. This account demonstrates that powers that were originally introduced as a mechanism that potentially enhanced the liberty of those arrested by the police have been transformed, as a result of the changing role of the police in the investigation of crime and the introduction of powers to attach conditions to bail, into a mechanism that threatens the liberty of those who are subjected to them. We go on to examine these powers by reference, in particular, to the right to liberty under Article 5 ECHR. We also, all too briefly, consider the implications of such powers for other rights under the Convention, in particular the right to private life (Article 8), the right to freedom of expression (Article 10), and the right to freedom of assembly and association (Article 11), and for the presumption of innocence (Article 6(2)).

${ }^{1}$ For example, "Lawyers to fight bail conditions that "stifle" climate protests", guardian.co.uk, 3 May 2009; "Didcot demonstrators: Police use bail restrictions to stifle climate protests", guardian.co.uk, 27 October 2009.

2 A notable exception were the proposed changes to the law relating to police bail conditions made by the Liberal Democrats. See HL Deb. vol. 713 col. 579 (20 October 2009).

Joint Committee on Human Rights, Second Report on the Criminal Justice Bill, HL (2002-02) 40.

${ }^{4} R(C)$ v. Chief Constable of A and A Magistrates' Court [2006] EWHC 2352 (Admin); R (Ajaib) v. Birmingham Magistrates' Court [2009] EWHC 2127 (Admin).

${ }^{5}$ See J. Raine and M. Wilson, "Police Bail with Conditions: Perspectives on the Use, Misuse and Consequences of a New Police Power" (1997) 37 British Journal of Criminology 593, and A. Hucklesby, "Police Bail and the Use of Conditions" (2001) Criminology and Criminal Justice 44, although both concern bail granted after charge. Ben Newton, in his chapter "Bail", in M. Colvin and J. Cooper, Human Rights in the Investigation and Prosecution of Crime (Oxford University Press, 2009), briefly considers the human rights implications of street bail but, although critical, does not pursue his analysis. Stefan Trechsel, in his otherwise comprehensive work Human Rights in Criminal Proceedings (Oxford University Press, 2005) does not consider police bail, and it is not considered in B. Emmerson, A. Ashworth and A. Macdonald, Human Rights and Criminal Justice ( $2^{\text {nd }}$ ed. Sweet and Maxwell, 2007) nor in K. Ewing Bonfire of the Liberties: New Labour, Human Rights, and the Rule of Law (Oxford University Press, 2010). 
We acknowledge that police bail powers also raise constitutional issues that we do not have space to consider. Although the police and their forerunners have had certain bail powers for centuries, there is at least a tension with the general principle that under the doctrine of the separation of powers such powers are essentially the preserve of the judiciary. ${ }^{6}$ Further, an examination of the development of police bail powers in the context of the "drift to summary justice", which has been identified and explored by a number of scholars, is beyond the scope of the article. ${ }^{7}$ Nevertheless, we hope that we have done enough to illuminate an area that ought to demand wider scrutiny and close attention.

\section{Police Bail Prior to the Police and Criminal Evidence ACT 1984}

In English law the grant of bail has never been an exclusively judicial activity, and since the advent of "modern" policing in the nineteenth century, alongside judicial bail there has always been a form of statutory bail $^{8}$ available to the police; 9 since the Metropolitan Police Act 1829 police constables have been able to grant bail in one form or another. ${ }^{10}$ This state of affairs appears not to have been the consequence of any deliberate decision. Rather the empowerment of the police was more a consequence of the chaotic circumstances that surrounded the establishment of the Metropolitan Police. Parliament granted that power to the new police no doubt because their predecessors had taken bail, but it sought to regulate what was undoubtedly an entrenched practice. ${ }^{11}$ The power to grant bail was seen as

${ }^{6}$ State of Mauritius v. Khoyratty [2006] UKPC 13; [2007] 1 A.C. 80.

7 See, for example, R. Young, "Street Policing after PACE: The Drift to Summary Justice" in E. Cape and R. Young (eds.), Regulating Policing: The Police and Criminal Evidence Act 1984 Past, Present and Future (Hart 2008), ch. 7, and R. Morgan, Summary Justice: Fast-but Fair? (Centre for Crime and Justice Studies, 2008).

${ }^{8}$ The police have no common law power to grant bail. See Williamson v. Chief Constable of the West Midlands [2003] EWCA Civ 337, (2003) 167 J.P. 181 at 192 [20] (Dyson LJ).

${ }^{9}$ Notwithstanding the contemporary centrality of police bail to the functioning of policing the historic roots of this power, essential for determining its proper ambit, have attracted very little detailed attention.

${ }^{10}$ See Metropolitan Police Act, 1829, s. 9; Metropolitan Police Act, 1839, ss. 70-72; Metropolitan Police Courts Act, 1840, s. 8; Metropolitan Police Act 1864, s. 2 (an Act passed to deal with antisocial street musicians); Town Police Clauses Act 1847, ss. 17-19; Summary Jurisdiction Act 1879, s. 38 (extending police bail to felonies in certain cases and amended by later Acts); Municipal Corporations Act, 1882, s. 227 (borough police empowered to grant bail); Criminal Justice Administration Act 1914, s. 22; Criminal Justice Act 1925, s. 45 (pre-charge bail); Magistrates Act 1952, s. 38 (consolidating and re-enacting previous provisions); and Magistrates Act 1980, s. 43.

${ }^{11}$ Even before the establishment of the Metropolitan police their forerunners were taking bail. The 1828 Select Committee on the Police of the Metropolis recorded in evidence that some SubstituteConstables were in the habit of taking bail from some defendants, particularly undergraduates at universities who had a propensity towards drink and violence. Bail taken in such circumstances, it seems, formed part of their remuneration, which is not altogether surprising as the police were largely unpaid. See the "Report from the Select Committee on the Police of the Metropolis" 1828 (533) Parliamentary Papers (1828) evidence of J S Thomas, 14th March 1828, K4 79. No doubt for 
useful for reasons of operational efficiency, if not practical justice. When the courts were not open the power to bail enabled the police to clear the watch-house of those accused of misdemeanors, frequently no more than the local drunks.

From the outset of modern policing the separation of powers between the police and the courts was somewhat blurred, and bail was not unique in this respect. ${ }^{12}$ This jurisdictional muddle was initially a matter of concern to Parliament, with the quasi-judicial powers of the police causing some anxiety. ${ }^{13}$ However, during the 1830 s these concerns were examined and largely dismissed as the police became established and were recognised as a significant improvement on their disorganised and unprofessional predecessors. Police power to grant bail only applied in respect of petty misdemeanors, although many saw advantages in the police being able to liberate those considered respectable who otherwise would have to be detained in the station pending the next sitting of the magistrates. ${ }^{14}$ The 1829 Act was limited, empowering the police to grant bail only to those detained in a watchhouse at night on condition that they appear at a magistrates' court on the following day it sat. ${ }^{15}$ However, if a person was brought to the watch-house during the day or on a Sunday the police had no power to bail them. In 1837 the Metropolitan Police Commissioners reported to a House of Commons Select Committee that this lacuna was causing practical difficulty, particularly at Christmas when police stations would rapidly fill with drunks who remained there for some days until the courts resumed business. ${ }^{16}$ Subsequently, the Select Committee recommended that the police power to grant bail be widened to prevent unnecessary detention in police stations. ${ }^{17}$ Indeed, some even advocated the extension of the power to bail to cases where felonies were alleged, ${ }^{18}$ and sure enough the power of the police to bail was gradually extended to include felonies as well. ${ }^{19}$ Thus by the end of the nineteenth century bail was firmly entrenched in the panoply of police powers. ${ }^{20}$ Whilst the

this very reason Metropolitan Police Act 1829, s. 9, prohibited constables from taking "any fee or reward" for granting bail.

12 The issue of warrants was another area where the separation of powers was blurred, much to the concern of the magistrates.

${ }^{13}$ Sir Leon Radzinowicz, History of English Criminal Law and its Administration Since 1750, Volume Four Grappling for Control (Stevens and Sons, 1968), pp. 193-194.

${ }^{14}$ In these circumstances the Secretary of State intervened to admit those detained to bail.

${ }^{15}$ C. Petersdorf, A Practical Treatise on the Law of Bail (Butterworths 1824), pp. 502-503.

16 Report from Select Committee on Metropolis Police Offices 1837-38 (578) Parl Papers (18371838) 33.

17 Select Committee Report (note 16 above) Recommendation No 11 p. 34.

${ }^{18}$ Select Committee Report (note 16 above) evidence of James Traill, magistrate, 37 Evidence. However, an earlier House of Commons select committee report in 1833 had argued that such an extension was not necessary.

${ }^{19}$ Summary Jurisdiction Act 1879, s. 38.

${ }^{20}$ The full extent of the powers is summarised very helpfully in the Report of the Royal Commission upon the duties of the Metropolitan Police, 1908 Cd. 4156 [42]-[43]. 
admission to bail has traditionally been considered a judicial function, in the case of police bail it seems to have been accepted, somewhat anomalously, that this was an executive function that was satisfactorily discharged by them for good practical reasons. ${ }^{21}$

Until 1925 police bail was available only after the police had decided to charge a suspect. In general a suspect would be charged by the station officer and then, if not held in custody, would be bailed, with or without a recognizance, to appear at the next court sitting. However, under the Criminal Justice Act 1925 the power of the police to bail a suspect before charge was made available. Paradoxically, given subsequent developments, when first enacted the power to release suspects before charge was seen as a necessary safeguard against police high-handedness and abuse. The change in the law arose from a now largely forgotten episode involving a decorated war veteran, Major Sheppard, who had been accused of theft by a prostitute. Sheppard was detained and interviewed in flagrant breach of the Judges' Rules and, no doubt because of his social standing, a statutory inquiry was ordered by the Home Secretary. ${ }^{22}$ The Rawlinson Inquiry concluded that Major Sheppard had not been promptly granted bail: "The real principle underlying the whole matter is that every person in custody who can safely be bailed has a right to be bailed at the earliest possible moment. It is vital that the police should bear this principle in mind. It was absolutely lost sight of in Major Sheppard's case". ${ }^{23}$ Rawlinson recommended that an amendment be added to the Criminal Justice Bill then before Parliament to enable pre-charge bail to be granted by the police. ${ }^{24}$ Introducing the amendment in the House of Lords the Lord Chancellor, Lord Cave, argued that the change would benefit both the police and the suspect. ${ }^{25}$ The measure was intended to ensure that individuals were not inconvenienced while, as in Major Sheppard's case, the threads of the inquiry were drawn together. In fact, The Law Times argued that the provision was to be seen in the same class as the Habeas Corpus Act as a safeguard of liberty and freedom. ${ }^{26}$

In 1929 the Royal Commission on Police Powers and Procedure reviewed the treatment of detainees in police custody, in part because of concerns about police abuse such as in the Sheppard case. ${ }^{27}$

${ }^{21}$ Report (note 20 above), p. 75 [12] and [14].

${ }^{22}$ C. Emsley, The Great British Bobby (London 2009), 208

${ }^{23}$ Report of an inquiry held by the Right Hon. J.F.P. Rawlinson, K.C., M.P., into the arrest of Major R. O. Sheppard (HMSO 1924-25), Cmd. 2497 p. 6.

${ }^{24}$ Note 23 above, p. 5.

${ }^{25}$ HL Deb. vol. 65 col. 263 (9 December 1925).

${ }^{26}$ The Law Times, 12th September 1925 vol. 160, p. 189.

27 1928-29 Cmd. 3297. For another example of custodial abuse see Report of the Tribunal appointed under the Tribunals of Inquiry (Evidence) Act, 1921, in regard to the interrogation of Miss Savidge by the Police 1928, Cmd. 3147. This inquiry led to important changes in the way that female suspects were interviewed. 
Although the power to release suspects on pre-charge bail had only recently been enacted the Commission considered its use an integral part of best practice. ${ }^{28}$ The "delayed charge" was a valuable power that should be used as "freely" as possible. ${ }^{29}$ As well as echoing the previously stated rationales for this power, the Commission argued that for the suspect it meant that he could be released pending further inquires without the stigma of a court appearance. The provisions thereafter became an accepted police power, and were consolidated and re-enacted in s. 38 of the Magistrates Act 1952.

Thus by 1925 the police had extensive powers to grant bail, both before and following charge. How, then was the power used in practice? Although there is scant official evidence, ${ }^{30}$ what evidence is available shows that in practice it slowly became not a safeguard for the liberty of the individual, but a tool of police investigatory convenience if not abuse. Bottomley and Pease, for instance, observed that by the 1980s police bail was used as a sifting procedure to select those people whom the police wanted to prosecute. Research conducted for the Royal Commission on Criminal Procedure, which reported in 1981, demonstrated that a third of all suspects who were not brought before a court had been initially bailed by the police. ${ }^{31}$

Police bail is a classic example of a low level broad discretionary power which is largely uncontrolled. That it has been abused is, therefore, hardly surprising. In something of a cause célèbre Mandy RiceDavies was arrested on what Bowes and Street agree was an irrelevant charge and then released on police bail of $£ 1,000 .{ }^{32}$ This was done, it seems, solely to ensure her attendance as a witness at the trial of Stephen Ward. This high profile case resulted in questions in the House of Commons and censorious coverage by newspapers, although neither the Attorney General nor the Home Secretary were prepared to admit there was any impropriety.

However, abuse was not limited to such high profile cases. In 1970 the Cobden Trust reported in its widely cited study Bail or Custody ${ }^{33}$

${ }^{28}$ Royal Commission on Police Powers and Procedures (1928-29) Cmd. 3297, ch. 5.

29 Note 28 above, [143]. The Commission thought that power was inappropriate in cases where the suspect was arrested on suspicion of having committed a serious offence, or where the suspect was of no fixed abode.

${ }^{30}$ K. Bottomley and K. Pease, Crime and Punishment: Interpreting the Data (Milton Keynes 1986), p. 66.

${ }^{31}$ R. Gemmill and R. Morgan-Giles, Arrest, Charge and Summons Research Study No. 9 (HMSO 1980) 21, Table 3.7, cited in Bottomley and Pease (note 30 above), 66. Between 8 and $17 \%$ of those in police custody were bailed under s. 38(2) for further inquires. A similar figure was later found by the Home Office Research Study No 185 Entry into the criminal justice system: a survey of police arrests and their outcomes by C. Phillips and D. Brown, 82 . However, $44 \%$ of bailed suspects had no further action taken against them, 83 .

${ }^{32}$ H. Street Freedom, the Individual and the Law (Harmondsworth 1967), pp. 26-27. A full account of the abuse of police bail in the case of Mandy Rice-Davies can be read in S. Bowes, The Police and Civil Liberties (London 1966), pp. 146-147.

${ }^{33}$ M King, Bail or Custody (London 1971). 
that the police were engaging in "bail bargaining", a process whereby bail was used to entice the suspect into making incriminating statements. ${ }^{34}$ This unlawful practice had surfaced in $R v$ Zaveckas $^{35}$ in which the Court of Appeal quashed a conviction based on a confession elicited from the defendant with the promise of bail. However, it was rare for such practices to come to light because, as the authors of the Cobden study noted, "it is extremely difficult to corroborate accounts by defendants of what went on behind closed doors of the police station". ${ }^{36}$ Furthermore, both the Cobden study and an earlier Home Office Study ${ }^{37}$ revealed that the initial decision of the police could have adverse consequences for the suspect later in the criminal justice system. For instance, there was a strong correlation between the initial police decision to grant or withhold bail, and the subsequent decisions of magistrates. Suspects who were granted police bail on condition that they appear in court were further remanded on bail by magistrates' courts in ninety two per cent of cases. ${ }^{38}$ The Cobden Trust argued not only that the police were, in effect, acting as judges in their own cause when granting bail but also that well-defined restrictions were needed on the power to grant bail. ${ }^{39}$ Nonetheless, these concerns were dismissed by the Working Party on Bail Procedures in Magistrates' Courts. ${ }^{40}$ The police would retain their "substantial discretionary powers" $"$ that had such an influence on the subsequent decisions of courts with respect to bail. ${ }^{42}$

\section{Police Bail Following the Police and Criminal Evidence ACT 1984}

The Police and Criminal Evidence Act (PACE) 1984 is commonly regarded as marking a significant change in the approach to the regulation of police powers, particularly those at the investigative stage of the criminal process. ${ }^{43}$ Many of its provisions were based on recommendations of the Royal Commission on Criminal Procedure (the Philips Commission), which reported in $1981 .{ }^{44}$ However, police

${ }^{34}$ Note 33 above, p. 8.

${ }^{35}$ [1970] 1 All E.R. 413

${ }^{36}$ Note 31 above, p. 6.

${ }^{37}$ Home Office Research Unit, The Use of Bail and Custody by London Magistrates Courts Before and After the Criminal Justice Act 1967, Report No 20 (HMSO 1974), p. 15.

${ }^{38}$ Note 37 above, p. 8.

${ }^{39}$ Note 33 above, p. 8 .

40 Report of the Working Party on Bail Procedures in Magistrates' Courts (HMSO 1974), 179-180.

${ }^{41}$ D. Galligan, "The Working paper on Bail" (1975) 38 MLR 59, 63.

${ }^{42}$ K. Bottomley, Decisions in the Penal Process (London 1973), pp. 87-88.

${ }^{43}$ For a comprehensive treatment see M. Zander, The Police and Criminal Evidence Act $19844^{\text {th }}$ ed., Londonl 2005), and for a critical analysis of the impact of PACE 1984 see E. Cape and R. Young (eds.), Regulating Policing: The Police and Criminal Evidence Act 1984 Past, Present and Future (Oxford 2008).

${ }^{44}$ RCCP, Report, Cmnd. 8092 (HMSO 1981). 
bail was treated by the Philips Commission as being largely uncontroversial. ${ }^{45}$ Despite the disquiet that had been voiced in the 1970 s, the only major concern expressed in evidence to the Commission was, as identified by the Cobden Trust a decade earlier, the danger of confessions being induced by the offer or perceived offer of bail. ${ }^{46}$ The only recommendation by the Commission in respect of pre-charge bail was that the police should have the power to re-bail a person who had surrendered following the earlier grant of police bail. ${ }^{47}$

As originally enacted, a number of provisions of the PACE 1984 permitted the police to bail a person without having charged them with an offence. Section 34(5) allowed a custody officer to grant bail to a person they were required to release under s. 34(2) because the grounds for detention had ceased to apply and there were no other grounds justifying their detention. Section 37(2) permitted the custody officer to release a person on bail where, having been arrested and brought to the police station, the officer did not have sufficient evidence to charge them with the offence for which they had been arrested. Section $37(7)(b)$ enabled a custody officer, having determined that there was sufficient evidence to charge, to release a person on bail as an alternative to charging them. This was in addition to the power of the custody officer to release a person charged with a criminal offence on bail pending their first court appearance. ${ }^{48}$ However, in none of these instances were the police permitted to impose conditions. In view of the subsequent introduction of "street bail", it is worth noting that the power to bail an arrested person without taking them to a police station was not considered by the Philips Commission, and did not feature in the PACE 1984 as originally enacted.

The Royal Commission on Criminal Justice (the Runciman Commission), reporting in 1993, went a step further than the Philips Commission by recommending that the police should have the power to impose conditions on granting bail, both where the suspect was released without charge and following charge. Allowing the police to impose conditions prior to charge "should lead to more thorough investigations"; and post-charge it "would reduce the suspect's liability to attend court". It would also mean that where a decision was made not to charge or to prosecute, the person would "be able to avoid a

${ }^{45}$ This is despite the fact that research that it had commission found evidence of such use. See P. Softley, Police Interrogation: An Observational Study in Four Police Stations, Research Study No 4 (HMSO 1980).

${ }^{46}$ Above note 42 , p. 58

${ }^{47}$ In respect of post-charge bail, the Commission recommended that the police should have the power to impose conditions.

${ }^{48}$ Section 38 permitted the custody officer to withhold bail on a number of grounds, which originally did not include fear of offences being committed although this was subsequently added. Apart from adding powers to impose conditions, the bail powers referred to have remained substantially the same. 
court appearance and any attendant publicity altogether" ${ }^{49}$ Like the Philips Commission, the Runciman Commission gave no consideration to the problems that might arise from extending police bail powers in this way even though research it had itself commissioned found that the police "were sometimes prepared to use their discretion over bail" as a tactic to induce a suspect to talk or to confess. ${ }^{50}$ The Runciman Commission's recommendation was partially implemented by the Criminal Justice and Public Order Act (CJPOA) 1994, s. 27(2)(a), which amended the Bail Act 1976, s. 3 and the PACE 1984, s. 47, to permit a security or surety to be required, and/or conditions to be imposed, where a person was granted bail following charge under the PACE 1984, s. 38(1).

For almost the next decade there were no significant changes to police bail powers. The Law Commission published a consultation paper on bail in $1999^{51}$ and published a final report, Bail and the Human Rights Act 1998, in 2001. ${ }^{52}$ Whilst the Commission considered police powers to grant or withhold bail post-charge, most of the report concerned bail from a court, and it specifically excluded consideration of police bail in respect of a person who had not been charged.

The next major statutory development was the Criminal Justice Act (CJA) 2003, which introduced the concept of street bail. This was prefigured by the government white paper Justice for All, published in $2002,{ }^{53}$ which in the then fashionable vernacular described the government's aim as being "to rebalance the system in favour of victims, witnesses and communities and to deliver justice for all, by building greater trust and credibility". Detailed consideration of changes to the PACE 1984 was left to the review of the legislation established by the then Home Secretary (the Joint Review), ${ }^{54}$ but the government was concerned to identify changes that "could simplify police procedures, reduce administrative burdens, save police resources and speed up the process of justice". ${ }^{55}$ In this context the white paper raised the question whether it was essential that all arrested persons be taken to a police station "for processing and interviewing", or whether some of them could be dealt with away from the police station, "thus saving police time". It no doubt had in mind the findings of the Home Office commissioned research, Diary of a Police Officer, which found that on average 43 per cent of a police officer's time was spent in the police

\footnotetext{
49 RCCJ, Report, Cm 2263, (HMSO 1993), p. 73.

${ }^{50}$ M. McConville and J. Hodgson, Custodial Legal Advice and the Right to Silence, Research Study No 16 (HMSO 1993), p. 121

${ }^{51}$ Consultation Paper No. 157

${ }_{52}$ HC 7, Law Com. No. 269 (Law Commission 2001).

${ }^{53}$ CM 5563 (HMSO 2002).

${ }^{54}$ Published as PACE Review: Report of the Joint Home Office/Cabinet Office Review of the Police and Criminal Evidence Act (Home Office, 2002).

${ }^{55}$ Note 54, p. 54.
} 
station, and that on average it took three hours to "process" a prisoner following an arrest. ${ }^{56}$ The Joint Review, published just days before the Criminal Justice Bill was introduced in Parliament in November 2002, ${ }^{57}$ recommended that the PACE 1984 be amended to allow a police officer to "offer an arrested person immediate bail from the scene of the arrest on condition that they must attend a specified police station at a specified time in the future" ${ }^{58}$ Other than stating that both "police officers and lawyers recognise the substantial benefits that [street bail] can offer in terms of saved resources and reduced re-offending rates", the report provided no evidence of the efficacy of street bail other than a reference to the Milton Keynes retail theft initiative model (which, in fact, did not involve street bail), and gave no indication that issues raised by such a radical departure from previous bail powers had been considered. The Review made no mention of a power to attach conditions to "street bail".

The Criminal Justice Act 2003 reflected the recommendations of the Joint Review regarding street bail by inserting four new sections into the PACE 1984, ss. 30A, 30B, 30C and 30D.${ }^{59}$ As originally enacted, the PACE 1984, s. 30, required a police officer, having arrested a person at a place other than a police station, to take them to a police station as soon as practicable after the arrest. There were only two exceptions to this obligation: first, the person could be "de-arrested" before being taken to a police station if the officer was satisfied that there were no grounds for keeping the person under arrest (s. 30(7)); second, the officer could delay taking the arrested person to a police station if their presence elsewhere was necessary in order to carry out "such investigations as it is reasonable to carry out immediately" (s. 30(10)), for example, to conduct a search of premises where the person was when they were arrested, or immediately before they were arrested, under the PACE 1984, s. 32.

Section 30 was amended by the CJA 2003 so that the obligation to take the arrested person to a police station was made subject to release on bail under a new s. $30 \mathrm{~A}$ (that is, "street bail"). ${ }^{60}$ Section $30 \mathrm{~A}$ empowers a police officer to release the arrested person on bail at any time before arrival at a police station, subject to a requirement that they

${ }^{56}$ PA Consulting Group, Diary of a Police Officer, Police Research Series Paper 149 (Home Office 2001), pp. 9 and 12 respectively. It was subsequently estimated that allowing an officer to bail an arrested person to attend a police station on a future date could save 390,000 hours of officers' time annually. See Policing Bureaucracy Taskforce, Street Bail: an Alternative to Immediate Detention, (Home Office 2004). For an analysis, see A. Hucklesby, "Not Necessarily a Trip to the Police Station: The Introduction of Street Bail" [2004] Crim. L.R. 803.

${ }^{57}$ See M. Zander, "The Joint Review of PACE: a Deplorable Report" (2003) 153 N.L.J. 204, and E. Cape, "Criminal Justice Act 2003 - no debate?" (2004) January Legal Action 6.

${ }_{58}^{58}$ Note 54 above, p. 23.

${ }^{59}$ By CJA 2003, s. 4.

${ }^{60}$ It also made the obligation specifically subject to the power to de-arrest the person under s. 30(7). 
attend a police station on a future date. On granting bail, the officer is required to give the person a written notice specifying the offence for which the person was arrested and the grounds of arrest, the police station that they are required to attend, and the time of attendance (s. $30 \mathrm{~B}(1)-(4)) .{ }^{61}$ No conditions on bail were permitted other than the requirement to attend a police station (s. 30A(4)). Failure to attend the specified police station at the specified time renders the person liable to arrest, although such failure is not an offence (s. $30 \mathrm{D}(1)$ ). In a sense, this was simply an enactment of an idea first mooted by the Philips Commission, namely the attendance notice. ${ }^{2}$ The Parliamentary Joint Committee on Human Rights concluded that the new power did not represent a significant interference with the ECHR Article $5 .{ }^{63}$ However, surprisingly, the grounds for releasing a person on street bail were not set out in statute, and there is no statutory obligation to give the arrested person notice of the grounds or reasons for releasing them on bail. Home Office Circular 61/2003, Criminal Justice Act 2003: Bail Elsewhere Than at a Police Station does set out factors that an officer is required to take into account in deciding whether to release an arrested person on street bail. These include: the type of offence for which the person has been arrested; ${ }^{64}$ whether a delay would lead to loss of vital evidence; whether the person is fit to be released; whether they understand what is happening; whether they are likely to commit further offences; and whether the officer is satisfied that the correct name and address has been given by the arrested person. The legislation imposes no lower age limit in respect of the use of street bail, although the Circular provides that where the arrested person is under 17 years of age, telephone contact should be made as soon as practicable with their parent, guardian or other carer.

The CJA 2003 made a further change to police powers to release a person on bail prior to charge in order to facilitate the statutory charging scheme that was also introduced by the 2003 Act, under which Crown Prosecutors took over many of the charging responsibilities of the police. Previously, having determined that there was sufficient evidence to charge, the custody officer was required to either charge the person or release them. Under the statutory charging regime, custody officers retain responsibility for determining whether there is sufficient evidence to charge under the PACE 1984, s. 37(7), but other than in minor cases or urgent situations, they must refer the case to a Crown

${ }^{61}$ Although if no police station or time is specified, it must subsequently be specified in a written notice (s. 30B(5)).

${ }^{62}$ See RCCP Report (note 44 above), para. 8.5.

63 Joint Committee on Human Rights, Second Report on the Criminal Justice Bill HL (2002-02) 40, paras. 36-42.

${ }^{64}$ In fact, the Circular states "What type of offence has been committed?" (emphasis added), providing an interesting, if disconcerting, insight into the Home Office attitude to due process. 
Prosecutor for them to make the charge decision. ${ }^{65}$ If the decision is that the person should be charged, the matter is then referred back to the custody officer to administer the charge, and to consider bail under the PACE 1984, s. 38. Section 37(7)(a) was amended to allow the custody officer to release the person on bail pending a decision as to charge by a Crown Prosecutor. Although many police stations now have a "co-located" prosecutor, at least during office hours, and CPS Direct has been established to permit contact with a prosecutor at times when a prosecutor is not physically present at a police station, ${ }^{66}$ this amendment gives custody officers some flexibility if a Crown Prosecutor is not immediately available.

For the first time, the police were also given the power to attach conditions to bail granted to a person not charged. This was done by way of an amendment to the PACE 1984, s. 47(1A), applying the "normal powers to impose conditions of bail" ${ }^{67}$ to bail under s. 37(7)(a). The amendment itself was buried in Schedule 2, para. 6(3), of the CJA 2003. This significant extension to police powers which, as explained below, was rapidly expanded to pre-charge bail granted under other provisions of the PACE 1984 by subsequent legislation, thus saw the light of day in a most unprepossessing way. The power to impose conditions had not figured in any of the pre-legislative reviews or white papers. The Explanatory Notes to the Act made no mention of the new power to impose conditions other than in respect of the power of arrest where conditions are broken, and the procedure to be followed under the PACE 1984, s. 37C, where such an arrest takes place. In other words, a major expansion of police powers which, we argue, has considerable constitutional and human rights implications, was simply surreptitiously slipped on to the statute book.

The next major Home Office consultation paper, Policing: Modernising Police Powers to Meet Community Needs, ${ }^{6}$ whilst making significant proposals to extend police powers of arrest, which were incorporated into the Serious Organised Crime and Police Act 2005, made no mention of police bail. ${ }^{69}$ Neither did the white paper Building

${ }^{65}$ See Director's Guidance on Charging, available at http://www.cps.gov.uk/Publications/ directors_guidance/dpp_guidance.html, and I. Brownlee, "The statutory charging scheme in England and Wales: towards a unified prosecution system?" [2004] Crim. LR. 896.

${ }^{66}$ For information on CPS Direct, see http://www.cps.gov.uk/direct/. For a critical account see J. Jackson, "Police and Prosecutors after PACE: The Road from Case Construction to Case Disposal" in E. Cape and R. Young, Regulating Policing: The Police and Criminal Evidence Act 1984 Past, Present and Future (Oxford 2008).

${ }^{67}$ Which has the meaning set out in Bail Act 1976, s. 3(6).

${ }^{68}$ (Home Office 2004).

${ }^{69}$ The Serious Organised Crime and Police Act 2005, Part 3, amended PACE 1984, ss. 24 and 25, and other legislation, to make all offences arrestable. See R. Austin, "The New Powers of Arrest: Plus ça change: More of the Same or Major Change?" [2007] Crim. L.R. 459; J. Spencer, "Extending the police state" (2005) N.L.J. 1 April, 477; and E. Cape, "Ever increasing police powers" (2005) February Legal Action 8. 
Communities, Beating Crime: a better police service for the $21^{\text {st }}$ century, ${ }^{70}$ also published in 2004, which was followed by the Police and Justice Act (PJA) 2006. However, the 2006 Act significantly extended the power of the police to impose conditions when releasing a person on bail, both street bail, and bail without charge from a police station.

In relation to street bail, the PJA 2006, s. 10 and Schedule 6, amended the PACE 1984, s. 30A, so that an officer releasing an arrested person on bail under s. $30 \mathrm{~A}(1)$ is empowered to impose such conditions as appear to the officer necessary:

- to secure the person surrenders to custody;

- to secure that the person does not commit an offence while on bail;

- to secure that the person does not interfere with witnesses or otherwise obstruct the course of justice; or

- for the person's own protection or, if the person is under the age of 17 , for the person's own welfare or in their own interests (s. $30 \mathrm{~A}(3 \mathrm{~B})) .^{71}$

The conditions cannot include a surety or security but, subject to some minor limitations, they are otherwise unrestricted provided that they are imposed for one of the statutory purposes. As the Parliamentary Joint Committee on Human Rights noted "conditions attached to the grant of bail can include various restrictions such as curfews, tagging, limits on the places a person can visit, or on people with whom they can speak or meet". ${ }^{72}$ This further extension of police powers rightly caused much concern. The extension of street bail could, in Liberty's opinion, cause "potentially severe restrictions on liberty that could remain in place indefinitely and could be used as a long lasting preventative measure" beyond the supervision of the courts. ${ }^{73}$ To balance the new power Liberty argued, unsuccessfully, that the bill should be amended to impose automatic time limits on the duration of street bail.

If conditions are imposed, the written notice that must be given to the person under s. 30B must specify the requirements imposed by those conditions, and explain the opportunity to apply for variation of the conditions, but does not have to state the grounds or reasons for imposition of the conditions (s. 30B(4A)). Provision was also made for the person to apply for variation of the conditions to a custody officer

\footnotetext{
${ }^{70} \mathrm{CM} 6360$ (Home Office 2004).

${ }^{71}$ It should be noted that whilst the provisions regarding conditional bail apply throughout England and Wales some police forces, such as Hampshire Constabulary, currently do not permit their officers to impose conditional street bail. See http://www.hampshire.police.uk/NR/rdonlyres/ A914C82D-C701-444F-96CE-DF8FBC487440/0/00901.pdf.

72 Joint Committee on Human Rights, Legislative Scrutiny: Tenth Progress Report HL 186 I/HC 1138 (2005-06), 1.11, a point later repeated in Joint Committee On Human Rights, CounterTerrorism Policy and Human Rights (Tenth Report): Counter-Terrorism Bill HL 108 (20072008), 50.

73 Briefing on the Police and Justice Bill 2006 (Liberty, London 2006), p. 11.
} 
or to a magistrates' court (ss. 30CA and 30CB), but not to challenge the decision to release them on bail. Section 30D was amended to empower the police to arrest the person if they have reasonable grounds for suspecting that they have broken any of the conditions, although breach of conditions is not an offence. The police may also arrest a person for failure to surrender to street bail.

The government conceded in its s. 19 Human Rights Act 1998 statement $^{74}$ that the extended powers have the potential to interfere with a range of Convention rights but nonetheless argued that any restrictions would be justified. ${ }^{75}$ These conclusions were supported by the Joint Committee. First, the Committee argued that the power to impose street bail was conditional, and subject to restriction. Second, the suspect must be provided with a notice specifying the conditions, and detailing how he might obtain a variation of them. Third, the custody officer has a power to vary those conditions, and thereafter the suspect may further apply to a magistrates' court. The Joint Committee concluded that "in view of these limits and safeguards, and in particular in light of the opportunity to go before a court to ask for the bail conditions to be varied, in our view the provisions in the Bill concerning police bail (sic) do not give rise to a significant risk of incompatibility with Articles 5, 8, 10 or 11 ECHR". ${ }^{76}$ The committee did not, however, consider whether or not the police should, in principle, have such a power and indeed whether, in a wider sense, such powers are compatible with Convention rights.

With regard to bail from a police station in circumstances where the person has not been charged the PACE 1984, s. 47(1A), was amended to permit conditions to be imposed whenever a person is released on bail under the PACE 1984, s. $37 .{ }^{77}$ Conditions can be imposed for the same purposes as under s. 30A, but in this case a surety or security can

${ }^{74}$ Under s. 19 the minister responsible for a bill must certify either that it is compatible with ECHR rights or that, despite the fact that it is not, he nevertheless wishes the House to proceed with consideration of it.

75 "432. Part 2 - Powers of police etc: police bail.

The provisions in Schedule 4 in respect of police bail engage Article 5 to the extent to which they permit an individual to be arrested or detained at a police station and permit the imposition of a condition restricting a person's movement to such an extent as to fall within the scope of Article 5 (for example, severe restrictions on a person's free moment). They may also engage Article 8 because they may interfere with the person's right to a private life (for example, a prohibition on visiting certain persons). Any interference with Article 5 would be justified under Article 5(1) (b) as being in order to secure the fulfilment of an obligation prescribed by law or under Article 5(1) (c) as being for the purpose of bringing the person before the competent legal authority on reasonable suspicion of having committed an offence. Any interference with Article 8 would be justified on the basis that it is necessary for the prevention of disorder or crime under Article 8(2)." Police and Justice Bill Explanatory Notes available at http://www.publications.parliament.uk/pa/ld200506/ ldbills/104/en/06104x-f.htm.

${ }^{76}$ Note 72 above at para. 1.15 .

${ }^{77}$ It does not extend to permitting conditions to be imposed where a person is released on bail without charge under other sections of PACE 1984, eg., under s. 34(5): $R$ (Torres) v. Commissioner of Police of the Metropolis [2007] EWHC 3212 (Admin). 
also be required. There are also similar provisions to those applying to street bail regarding variation of conditions and arrest for breach of conditions, and for failure to surrender (PACE 1984, ss. 30D, 46A(1), and 47(1D) and (1E), and Bail Act 1976, s. 3A(4)).$^{78}$ Unlike street bail, the custody officer must give reasons for imposing conditions, both orally and in writing (Bail Act 1976, s. 5A(2) and (3)).

The provisions governed by s. 47(1A) affect two distinct classes of people. Where an arrested person is taken to a police station, the custody officer must initially determine whether there is sufficient evidence to charge the person with the offence for which they were arrested (s. 37(1)). If the officer decides that there is insufficient evidence to justify a charge they must release them (on bail or without bail) unless detention is necessary for the purposes of the investigation. It was held in $R$ (Torres) v Commissioner of Police of the Metropolis ${ }^{79}$ that release on conditional bail under s. 37(2) is possible at any point during police detention where the custody officer has not (yet) determined that there is sufficient evidence to charge. Thus conditional bail, including a surety or security, can be imposed on a person where there is no more evidence that they committed an offence than that required for the purposes of arrest. The second class of person is that where the custody officer has determined under s. 37(7) that there is sufficient evidence to charge. In these circumstances, the officer can bail the person pending a charge decision by a Crown Prosecutor (s. 37(7)(a)(i)), or can bail them "not for that purpose" (s. 37(7)(b)). The latter provision enables the custody officer to bail a person where they wish to continue the investigation or, for example, to allow consideration to be given to a conditional caution. ${ }^{80}$ It should be noted that the meaning of "sufficient evidence to charge" is both problematic and controversial. ${ }^{81}$ The current version of the DPP's Guidance on Charging ${ }^{82}$ provides that

\footnotetext{
${ }^{78}$ Note that the government has proposed that the power to impose conditions be extended to precharge bail granted under other provisions in the PACE 1984, that the police should have powers of arrest in respect of anticipated breach of conditions or anticipated failure to surrender to custody, and that failure to surrender to street bail be made a criminal offence. See Modernising Police Powers: Review of the Police and Criminal Evidence Act (PACE) 1984: Consultation Paper (Home Office 2007), and PACE Review: Government proposals in response to the Review of the Police and Criminal Evidence Act 1984 (Home Office August 2008).

79 [2007] EWHC 3212 (Admin). The custody officer had purported to impose conditional bail under s. 34(5), which is not permissible, but the court held that where a custody officer had not determined that there was sufficient evidence to charge, the police had a choice of which section to use, and using s. 37(2) would enable them to impose conditions.

${ }^{80}$ Conditional cautions, which are a matter for a Crown Prosecutor, are governed by the CJA 2003 Part 3. It should be noted that s. 37 is not satisfactory in that where a person is bailed under s. 37(7)(b), arguably they cannot be further detained for questioning or investigation when they surrender to bail since, under s. 37(1), the custody officer must decide whether there is sufficient evidence to charge (which, of course, has already been determined before bail was granted) and, determining that there is such evidence, must deal with the person under s. 37 .

${ }^{81}$ See $G$ v. Chief Constable of West Yorkshire Police [2006] EWHC 3485 (Admin), and for an analysis see E. Cape, "Police Bail and the Decision to Charge: Recent Developments and the Human Rights Deficit" (2007) Archbold News 7, 6.

${ }^{82}$ See note 65 above.
} 
in determining whether there is sufficient evidence to charge under s. 37 for the purpose of deciding whether to refer the case to a Crown Prosecutor for a charge decision, the custody officer should apply the Threshold Test. This test is defined as an "assessment of whether... there is at least a reasonable suspicion against the person of having committed an offence... and that at that stage it is in the public interest to proceed". ${ }^{83}$ Thus, apart from the public interest element, the threshold for deciding whether to bail a person under s. 37(7) is, as with bail under s. 37(2), potentially no higher than that required for the initial arrest.

Consequently, a person can be subjected to conditional bail, whether street bail or bail from a police station, in circumstances where, at most, there is only a reasonable suspicion that they have committed an offence. In fact, since some arrest powers do not require reasonable suspicion, that is those under the PACE 1984, s. 24(1)(a), (b) and (3)(a), a person can be subjected to conditional bail even though the grounds for suspicion do not satisfy the requirements of reasonable suspicion. In any event, the case law on reasonable suspicion sets a very low threshold ${ }^{84}$ and in forming a suspicion the officer can rely on hearsay and other information that would not amount to admissible evidence..$^{85}$ Research evidence suggests that even this low threshold does not impose a significant limitation on the police, leading Sanders and Young to conclude that it "is such a low threshold that most arrests are based on weak evidence, and many are based on virtually no evidence". ${ }^{86}$

\section{Key Features of Police Bail without Charge}

As noted earlier, when the power of the police to grant pre-charge bail was first enacted it was regarded as being beneficial to suspects, enabling them to be released from custody, and possibly avoid a court appearance altogether. However, pre-charge bail then operated in a significantly different context than in the modern era. Arrest applied at a different point of an investigation in 1925. Arrest would have

${ }^{83}$ Director's Guidance on Charging, note 65 above, at [3.10]. The test in the revised Code for Crown Prosecutors, which came into force in February 2010, retains the reasonable suspicion test, but also requires the Crown prosecutor to be satisfied that there are reasonable grounds for believing that further evidence sufficient to satisfy the full code test will become available within a reasonable period of time.

${ }^{84}$ See, for example, Castorina v. Chief Constable of Surrey (1988) 138 N.L.J. 180; O'Hara v. Chief Constable of the Royal Ulster Constabulary [1997] AC 286; Al Fayed v. Metropolitan Police Commissioner [2004] EWCA Civ 1579; Chief Constable of West Yorkshire v. Armstrong [2008] EWCA Civ 1582; and Alford v. Chief Constable of Cambridgeshire [2009] EWCA Civ 100. Contrast $R$ v. Olden [2007] EWCA Crim 726; and Commissioner of Police for the Metropolis v. Raissi [2008] EWCA Civ 1237.

${ }^{85}$ See, for example, King v. Gardner (1979) 71 Cr App R 13, and Clarke v. Chief Constable of North Wales Police [2000] All E.R. (D) 477.

${ }^{86}$ A. Sanders and R. Young, Criminal Justice ( $3^{\text {rd }}$ ed., Oxford 2007), p. 164. 
occurred at the end of a police investigation, when it was necessary to bring a person before a court ${ }^{87}$ or because a judicial warrant had been issued. ${ }^{88}$ As recently as 1970 Lord Devlin observed that "as a general rule $[. .$.$] an arrest should not be made until the case is complete" { }^{89}$ As a result, police bail was a short term convenience. Today, however, an arrest is usually the starting point in an investigation..$^{90}$ All that need be sufficient for the arrest to take place is, at most, a "reasonable suspicion" which, as demonstrated earlier, amounts to a low threshold that in practice is often ignored. As arrest has migrated within the investigative phase of criminal investigation, so that it may now be exercised at the inception of an investigation rather than at the end, the power to bail persons arrested has taken on a different character. Rather than being used for short periods in a manner protective of liberty it now has the potential, as Liberty pointed out, to be used by the police as a tool to control suspects for lengthy periods of time. ${ }^{92}$

Nevertheless, might it not be argued that police bail, particularly when it is granted unconditionally, continues to fulfill a function that enhances the liberty of the suspect? It is often assumed that a person released on bail is simply at liberty, and that bail thus enhances liberty. Clearly such a person is no longer in detention or imprisoned, ${ }^{93}$ but are they at liberty? Historically, a person on bail was described as being "at large on bail", and their condition was described as being in a "living prison". ${ }^{94}$ The surety was, in effect, a gaoler or keeper of the principal. In fact so entrenched was the position and function of the surety that where the accused did not have any sureties the gaol was, in effect,

87 John Lewis \& Co v. Tims [1952] A.C. 676, 691-2 (Lord Porter). Although Tims concerned arrest by store detective Lord Porter was careful to say that his remarks applied, mutatis mutandi, to police officers (680).

${ }^{88}$ Before 1967 this is all that the common law would have permitted; Criminal Law Act 1967, s. 2.

89 Hussein v. Chong Fook Kam (1970) A.C. 942, 948 (Lord Devlin). In this Lord Devlin was echoing Lord Porter in Tims: "Those who arrest must be persuaded of the guilt of the accused; they cannot bolster up their assurance or the strength of the case by seeking further evidence and detaining the man arrested meanwhile or taking him to some spot where they can or may find further evidence" (691).

90 Holgate-Mohammed v. Duke (1984) A.C. 437, 441-442 (Lord Diplock).

91 A position that has been held to be acceptable under the ECHR. See for example Murray v. United Kingdom [1994] ECHR 14310/88. It must be said that the reasoning of the majority in this case is far from convincing.

92 This is an unhappy legacy of the effect of the decisions in cases such as Dallison v. Caffery [1965] 1 Q.B. 348 and Holgate-Mohammed v. Duke [1984] A.C. 437 that allowed the police to use arrest as an investigatory tool. In these cases no thought was given to the wider implications of allowing the police to arrest for investigations rather than to bring a person suspected of offending before a magistrates' court.

93 Syed Mahamad Yusuf-Ud-Din v. Secretary of State for India in Council (1903) 19 T.L.R. 496, 497 (Lord MacNaghten). In Syed the Privy Council held that once a prisoner was freed on bail he was no longer imprisoned and could not thus bring an action for false imprisonment for the time he spent on bail. The decision of the Judicial Committee is per incuriam. The cases referred to below were not cited before the Committee or referred to in its judgment.

94 E. de Haas, "Concepts of the Nature of Bail in English and American Criminal Law" (1946) 6 University of Toronto Law Journal 385, 393. The phrase comes from the account found in the L'Ancienne Coutume de Normandie.: the "accused was considered as being held by the sureties in lieu of a prison of stone and mortar" (de Haas, (393)). 
considered to be the surety. ${ }^{95}$ Bailed defendants were considered to be in custody. ${ }^{96}$ Thus, for instance, Babington $\mathbf{J}$ concluded that "he who is all the time under bail, the law adjudges him in prison". ${ }^{97}$ Moreover, "the bail have their principal always upon a string, and may pull the string whenever they please" ${ }^{98}$ The admission to bail was therefore only a change in custody. ${ }^{99}$ This traditional view of bail was to some extent undermined by the Bail Act 1898, which empowered justices to dispense with sureties if they decided it was in the interests of justice to do so, ${ }^{100}$ and the Bail Act 1976, under which bail is to be normally granted without sureties. ${ }^{101}$ However, this does not mean that being "at large on bail" can simply be equated with being at liberty or, indeed, that bail should necessarily be seen as enhancing liberty.

As noted earlier, a person who has been granted bail by the police can be arrested if they fail to surrender on the due date. If conditions are imposed, they can be arrested for failure to comply with those conditions. ${ }^{102}$ There is no time limit on street bail or pre-charge bail, and in respect of the latter no limitation on repeated releases on bail. ${ }^{103}$ Proposed amendments to the Police and Justice Bill, which would have limited conditions attached to street bail to a maximum of 72 hours, were rejected by the government. ${ }^{104}$ In the absence of official statistics

95 de Haas (note 94 above) 393-394.

${ }^{96}$ The early English case law is meticulously catalogued in de Haas, and is drawn upon here.

${ }^{97}$ Year Book, 4 Hen. VI at 8 pl. 21.

98 Anon (1704) 6 Mod. Rep. 231. This is a view long approved by the Supreme Court of the USA: "When bail is given the principal is regarded as delivered to the custody of his sureties. Their dominion is a continuance of the original imprisonment" (Taylor v. Taintor 83 U.S. 366, 371-372 (1872)). Following the decision of the USA Supreme Court in Leary v. United States 224 U.S. 567, 575-576 (1912) a contract system of bail replaced the common law one. This is an approach contrary to public policy in English law: "When a man is ordered to find bail, and a surety becomes responsible for him, the surety is bound at his peril to see that his principal obeys "the order, of the Court: at least, this is the, rule in the criminal law; but if money to the amount for which the surety is bound is deposited, with him as an indemnity against, any loss which he may sustain, by reason of his principal's conduct, the surety has no interest in taking care that the condition of the recognisance is performed. Therefore the contract between the plaintiff and the defendant is tainted with illegality" (Herman v. Jeuchner (1884-85) L.R. 15 Q.B.D. 561, 563 (Brett MR)).

99 Foxall v. Barnett (1853) 23 L.J.Q.B. 7, 8 (Coleridge J ).

100 A. Bottomley, "The Granting of Bail: Principles and Practice" (1968) 31 M.L.R. 40, 49 Parliament acted because the poor were needlessly detained as a result of being unable to find sureties with sufficient resources, and the view was formed that the poor need not provide sureties as they were less likely to abscond.

${ }^{101}$ Schedule 2 of the Bail Act 1976 dispensed with the term "at large on bail" so far as statute is concerned. but see $R$ v. Rebecca Saw [2009] EWCA Crim 1, [2009] 2 Cr. App. R (S) 54, 43 (Judge LCJ).

102 For the former Labour government's proposals to extend powers of arrest to anticipated breach of conditions or failure to surrender to custody, and to make them criminal offences, see note 78 above.

103 This may be contrasted with police bail post-charge where, under PACE 1984, s. 47(3A), the date of the first court appearance must normally be no later than the first sitting of the relevant magistrates' court after the person is charged. It may also be contrasted with bail from a court where, whilst there are no time limits in relation to bail itself, there are in practice a number of factors limiting the period for which a defendant will be on bail.

${ }^{104}$ House of Commons Standing Committee D, 21 March 2006, Hansard cols. 136-138. The policy guidance issued by the Kent Police states that normally street bail should have a return date of no 
or research evidence on the use of police bail, we have to rely on anecdotal evidence. This suggests that it is not unusual for suspects to be released on pre-charge bail for six months, and in some cases for them to be re-bailed for similar periods on a number of occasions. Prolonged release on pre-charge bail was unsuccessfully challenged in $R(C) v$ Chief Constable of $A$ and $A$ Magistrates' Court. ${ }^{105}$ The applicant, having been arrested in connection with offences concerning child pornography, was then bailed without charge for a period exceeding six months. ${ }^{106} \mathrm{He}$ argued, inter alia, that this imposed severe restrictions on his business activities which frequently took him abroad. The Divisional Court, whilst stating that it was not the case that it would never intervene in a criminal investigation, said that intervention would only be appropriate in the most exceptional circumstances, and this case did not satisfy that requirement.

Despite the fact that police bail may have serious implications for the liberty of the suspect, both street bail and pre-charge bail are available irrespective of the seriousness of the suspected offence and, therefore, conditional bail can be imposed however minor the offence for which a person has been arrested and/or detained. Indeed, in the case of street bail, Home Office Circular 61/2003 discourages its use in more serious cases, stating that it is unlikely that it would be granted "in relation to a serious arrestable offence" ${ }^{107}$ In order for conditions to be imposed, the relevant officer must simply consider that they are necessary for one or more of the statutory purposes. It was held in $R v$ Mansfield Justices ex $p$ Sharkey, ${ }^{108}$ in relation to bail conditions imposed by a court, that the perceived risk must be real, and not merely fanciful. Although similar principles should apply to police bail, the process by which the bail decision is made does not allow for the necessity of the conditions to be tested. There is no provision (either in statute or the PACE Codes of Practice) for the suspect to make representations, either about bail itself or as to conditions. ${ }^{109}$ Even if they are able to make representations, there is no obligation on the police to take them into account in making their decision. Although reasons must be given for any conditions imposed on pre-charge bail, this is not

more than two weeks, although it does envisage that it could be up to six weeks, or even longer in exceptional circumstances.

105 [2006] EWHC 2352 (Admin).

106 This was unconditional bail, since the provision of Police and Justice Act 2006 had not then been brought into effect, but it is unlikely that it would have made any difference if conditions had been imposed since, in any case, the court could have varied or removed the conditions.

107 Home Office Circular 61/2003 Criminal Justice Act 2003: Bail Elsewhere than at a Police Station, section C. Since this circular was issued, the category of "serious arrestable offence", previously defined in PACE 1984, s. 116 and Sch. 5, has been abolished by CJA 2003, Sch. 7, para. 43. Some police forces, in their internal guidance, also stress that street bail will normally only be suitable in relation to minor offences. See, for example, Kent Police Policy Document N64 Bail, para 19.2.

108 [1985] Q.B. 613.

109 Again, this may be contrasted with court bail. 
the case for street bail, and there is no obligation on the police to articulate grounds for the decision to bail.

In its report Bail and the Human Rights Act 1998 the Law Commission emphasised the importance of proportionality in relation to the imposition of bail conditions. ${ }^{110}$ Since, as noted earlier, the police have the power to arrest for any offence however minor, and given that conditional police bail is available where a person has been arrested in respect of any offence, the issue of proportionality is left to each individual officer making a bail decision. This is stressed in the policy guidance issued by a number of police forces ${ }^{111}$ but the Home Office Circular on street bail, whilst requiring that officers use the power "fairly, objectively and without any bias against ethnic or other groups within the community", ${ }^{112}$ makes no explicit reference to the need to apply bail powers in a proportionate way. ${ }^{113}$ This is of particular importance in respect of street bail because the bail decision is made by the arresting officer, who will normally be of constable rank (as compared to a custody officer at a police station who must normally be of the rank of at least sergeant), ${ }^{114}$ and in circumstances where none of the due process safeguards that apply at a police station, such as the requirement to make a record of the decision in the custody record, ${ }^{115}$ custody suite CCTV, and access to legal advice, are available or applicable.

\section{Police Bail And Article 5 ECHR}

Article 5 (1)(c) ECHR permits a deprivation of liberty by "the lawful arrest or detention of a person effected for the purpose of bringing him before the competent legal authority on reasonable suspicion of having committed an offence or when it is reasonably considered necessary to

${ }^{110}$ See, for example, Bail and the Human Rights Act 1998, HC 7, (Law Commission 2001) at 73 and 81. In its submission to the Commission, the Metropolitan Police expressed concern that bail conditions (following charge) were being imposed for non-imprisonable offences where there were no grounds for detaining the person in custody pending their court appearance.

111 For example, Kent Police (see note 107 above), at para 13.2 in respect of bail granted by a custody officer, although this is not explicitly repeated in respect of street bail decisions.

112 Note 107 above, at para. A.5.

113 It should be noted that neither the legislation nor Home Office Circular 61/2003 makes any special provision in respect of juveniles beyond, in the case of the latter, requiring the parent or carer to be informed. Despite the fact that Youth Justice Board guidance emphasises the importance of bail supervision and bail support schemes for juveniles, the provisions regarding street bail and precharge bail apply to juveniles in the same way as they apply to adults except that conditions can additionally be imposed on a juvenile for their own welfare or in their own interests. There is no equivalent to the Children and Young Persons Act 1933, s. 44(1), which requires a court when dealing with a child or young person to have regard to their welfare.

114 PACE 1984, s. 36(3).

115 Bail Act 1976, s. 5A. A suspect's lawyer has a right to inspect the custody record as soon as practicable after their arrival at a police station (PACE Code of Practice C, para. 2.4), and the suspect and their lawyer are entitled to a copy of the custody record if a request is made when the person is taken to court or within 12 months of release from police detention (PACE Code C, para. 2.4A) 
prevent his committing an offence or fleeing after having done so"; provided always that this is in accordance with a procedure prescribed by law. However, this power to interfere with liberty is circumscribed by Article 5(3) which provides that where a person is so arrested or detained they "shall be brought promptly before a judge or other officer authorised by law to exercise judicial power and shall be entitled to trial within a reasonable time or to release pending trial. Release may be conditioned by guarantees to appear for trial". The European Court of Human Rights (ECtHR) has consistently held that the purpose of Article 5 is not only to prevent incommunicado detention but also arbitrary deprivations of liberty by the police and other agents of the state. ${ }^{116}$ Given that Article 5 is a right of primary importance in a democracy, ${ }^{117}$ a person is "not to be deprived, or to continue to be deprived, of their liberty save in accordance with the conditions specified in paragraph 1 of Article $5 .$. . [and that] list of exceptions ... is an exhaustive one and only a narrow interpretation of those exceptions is consistent with the aim of that provision, namely to ensure that no one is arbitrarily deprived of his or her liberty" ${ }^{118}$ Where a person is suspected of having committed a criminal offence there is a balance to be struck between the liberty of the individual, who is presumed to be innocent, and the interests of the state in the administration of justice, which includes the prosecution of offenders. A court of law or judicial officer provides an independent and impartial mechanism by which these conflicting interests can be fairly and impartially weighed.

Closely associated with the right to liberty is the presumption of innocence. ${ }^{119}$ Judicial bail and, indeed, bail following charge plays a vital role in protecting the presumption of innocence. As Vinson CJ put it "unless the right to bail before trial is preserved, the presumption of innocence, secured only after centuries of struggle, would lose its meaning" ${ }^{120}$ The presumption of innocence is more than a mere rule of evidence, ${ }^{121}$ it is a bulwark against the imposition of punishment before conviction. It is often asserted, particularly in common law jurisdictions, that the guarantees of Article 6, and thus Article 6(2), apply from the point of charge. However, it has been recognised in domestic law that some of the guarantees of Article 6 also have application at the pre-charge stage. ${ }^{122}$ The ECHR has also ruled that Article 6(2) can apply prior to the point at which formal criminal proceedings are

116 Asseov v. Bulgaria [1998] ECHR 24760/94, at [146].

117 McKay v. United Kingdom [2006] ECHR 543/03 [30].

118 Ladent v. Poland [2008] ECHR 11036/03, at [45]-[46].

119 Now given statutory force in the United Kingdom by virtue of Human Rights Act 1998, Sch. 1.

120 Stack v. Boyle, 342 U.S. 1, 4 (1951).

121 M. Zander, "Bail: A Re-appraisal” [1967] Crim. L.R. 25, 26.

122 Dumbell v. Roberts [1944] 1 All ER 326, 329 (Scott L.J.): "The British principle of personal freedom, that every man should be presumed innocent until he is proved guilty, applies also to the police function of arrest". 
commenced, ${ }^{123}$ and thus the application of the presumption of innocence is not limited to trial proceedings, but covers also the investigatory phase. Thus it has been held that that Article 6 can be engaged when a person is "substantially affected" by criminal proceedings. ${ }^{124}$ Furthermore, the ECtHR has interpreted Article 5(3) as protecting the presumption of innocence. The guarantee in Article 5(3) applies irrespective of whether the authorities have charged someone or not: "Article 6(2) governs criminal proceedings in their entirety", from the point of arrest through to the determination of guilt. ${ }^{125}$ As Duff remarks, the presumption "requires courts to see the defendant as a citizen who has committed no criminal wrong unless and until it is proved that she is guilty of a particular wrong". ${ }^{126}$ The suspicion that a person might have committed a crime "does not warrant treating him as guilty", ${ }^{127}$

The presumption of innocence is relevant not just in relation to remands in custody but also to bail conditions. Under the ECHR bail conditions can only be lawful if they respect the presumption of innocence. Preventative pretrial restrictions on liberty that are predicated on the assumption that they are necessary to prevent further offending are incompatible with the presumption of innocence. ${ }^{128}$ Thus in Nerattini v. Greece ${ }^{129}$ the applicant had been refused bail by the Samos Criminal Court, in part because it feared that if released he would commit similar offences on bail. ${ }^{130}$ Even before the applicant had been charged or convicted the Court refused bail on the basis that he showed a "propensity to commit further offences relating to antiquities". ${ }^{131}$ The ECtHR held that this prejudicial labeling constituted an interference with the presumption of innocence. The presumption of innocence, of course, may be infringed by statements and actions of public authorities other than courts. ${ }^{132}$ "The presumption of innocence", the

${ }^{123}$ In Fatullayev v. Azerbaijan [2010] ECHR40984/07 the European Court held that once the applicant had been detained during an investigation, though not formally indicted, Article 6(2) applied [155].

124 Serves v. France [1997] ECHR 82/1996/671/893, at [42]; Eckle v. Germany [1982] ECHR 8130/78, at [73]. The narrow and literal approach of the English courts is at odds with this. See $R$ (Ajaib) v. Birmingham Magistrates Court [2009] EWHC 2127 (Admin) at [40] (Dobbs J), in which it was held that Article 6 had no application to pre-charge bail since the applicant was not the subject of a criminal charge. With respect this must be wrong. Whilst the extent of the rights that apply precharge is not necessarily as extensive as those that apply during the trial it is wrong both in principle and as a matter of authority to seek to place the articles of the ECHR in watertight compartments. See Murray v. UK [1996] 18731/91. For an analysis of ECtHR jurisprudence on the application of Article 6 ECHR to the investigative stage, see E. Cape, Z. Namoradze, R. Smith and T. Spronken, Effective Criminal Defence in Europe (Antwerp 2010), ch. 2.

125 Garycki v. Poland [2007] ECHR 14348/02, at [68].

126 A. Duff, Answering for Crime (Oxford 2008), p. 196.

${ }^{127}$ Duff (note 126 above), p. 197.

128 Lavents v. Latvia [2008] ECHR 58442/00, at [70].

${ }^{129}$ Nerattini v. Greece [2008] ECHR 43529/07, at [34].

${ }^{130}$ Nerattini, at [21]

131 Nerattini, at [25].

${ }^{132}$ Allenet de Ribemont v. France [1996] ECHR 15175/89, at [36]. 
ECtHR held in Garycki v Poland, "will be violated if a judicial decision or a statement by a public official concerning a person charged with a criminal offence reflects an opinion that he is guilty before he has been proved guilty according to law ... It suffices, even in the absence of any formal finding, that there is some reasoning suggesting that the court or the official regards the accused as guilty". ${ }^{133}$ This is particularly important in where the officer in question is exercising quasi-judicial functions. ${ }^{134}$ Consequently it is arguable that the imposition of conditional bail by police officers could in some cases be contrary to the presumption of innocence; and where an officer attaches conditions that are not trial related there is an attendant risk that the resulting prejudicial aura of guilt may undermine the presumption of innocence of the suspect in any subsequent judicial proceedings.

\section{A. Prompt production before a judge}

European Court of Human Rights jurisprudence on Article 5(3) requires that production before a judge be both automatic and prompt. ${ }^{135}$ Within the terms of Article 5 once a person is arrested or detained the temporal guarantees begin to run. ${ }^{136}$ Article 5(3) does not refer to arrest and detention, but to arrest or detention. Therefore, it would seem that the judicial review required by Article 5(3) is triggered by the arrest (or detention) itself. This is nothing out of the ordinary since it is little more than a statutory articulation of the old English common law practice whereby an arrest was a mechanism for producing a person before a court. Article 5 does not provide for any exception that authorises the conditional release of an arrestee or detainee who, even on police bail, continues to be substantially affected by proceedings against him and thus within the protective ambit of both Article $5^{137}$ and $6 . .^{138}$

${ }^{133}$ [2007] ECHR 14348/02, at [66].

134 Daktaras v. Lithuania [2001] ECHR 42095/98, at [42]: "Moreover, the principle of the presumption of innocence may be infringed not only by a judge or court but also by other public authorities, including prosecutors. This is particularly so where a prosecutor, as in the present case, performs a quasi-judicial function when ruling on the applicant's request to dismiss the charges at the stage of the pre-trial investigation, over which he has full procedural control".

${ }_{135}$ Aquilina v. Malta [1999] ECHR 25642/94, [49].

${ }^{136}$ And in the domestic context this is recognised by the fact that a person cannot be detained without charge for longer than 36 hours before they must be produced to a magistrates' court (PACE 1984, ss. 41 and 42 ).

${ }^{137}$ For example in Rokhlina v. Russia [2005] ECHR 54071/00 the ECtHR held that for the purposes of the Convention the applicant was "charged" when she was arrested on suspicion of murdering her husband and taken into custody, even though she was not formally charged under Russian law until some time later.

138 Article 6 will apply when a person is "charged". The ECtHR has defined this "as the official notification given to an individual by the competent authority of an allegation that he has committed a criminal offence" (Deweer v. Belgium [1980] ECHR 6903/75, at [46]). While Article 6 does not fully apply until the suspect is formally charged, parts of that Article do apply at the pretrial stage in order that the rights of the defence are not subsequently prejudiced. 
Nothing in Article 5(3) excuses the state from bringing a person arrested within the terms of Article 5(1)(c) promptly before a judge of judicial officer. ${ }^{139}$ This obligation does not apply where a person is arrested or detained for the purpose of securing the fulfillment of an obligation prescribed by law, which is a permissible interference with liberty under Article 5(1)(b). The government argued that this, inter alia, was a reason why street bail would not contravene Article 5 rights. ${ }^{140}$ However, the power to impose street bail applies where a person has been arrested for an offence (thus coming within Article $5(1)(c))$, not where a person has been arrested in order to secure the fulfillment of an obligation. It is the purpose of the arrest which is relevant to whether this exception to the right to liberty applies, not the purpose of the obligation.

Although Article 5(3) makes no reference to such a possibility, the police are almost certainly absolved of the responsibility of prompt production if the person is "de-arrested", that is, released without bail and unconditionally. ${ }^{141}$ However, release on police bail can hardly be regarded as a "de-arrest" and it is not recognised as such by PACE 1984. As noted earlier, even if no conditions are attached to bail the person is under a legal duty, on pain of criminal sanction in the case of pre-charge bail (but not street bail), to surrender to bail on the due date, and failure to surrender may result in their further arrest. Under English law there is no automatic judicial review of the arrest or bail decision. In fact, there is no review of an arrest at all unless the arrestee commences legal proceedings for that purpose, or argues for exclusion of evidence on the grounds of unlawful arrest in a criminal trial. With regard to a police bail decision, there is no automatic judicial oversight. If it is unconditional, the person bailed may bring judicial review proceedings, but the courts have demonstrated a marked reluctance to intervene. ${ }^{142}$ In the case of conditional street bail the bailed person cannot even make an application to a court to review any conditions imposed until they have, at least, requested the police to vary the conditions.

It might be argued that the drafters of Article 5 accurately reflected policing practice at the time that the Convention was drafted, ${ }^{143}$ and did not anticipate either the requirements of modern policing with its need, in some cases, for lengthy investigation commencing with an arrest, or

\footnotetext{
139 The exceptions to the right to liberty contained in Article 5 are exhaustive and strictly defined. They are to be construed narrowly in a way that favours the individual: Ilijkov v. Bulgaria [2001] ECHR 33977/96, at [85].

${ }^{140}$ See note 75 above.

141 The possibility of which is recognised by PACE 1984, s. 30(7) and (7A), although this terminology is not used in the legislation.

${ }^{142}$ See the text to note 105 above.

143 John Lewis v. Tims [1952] AC 676.
} 
the statutory sanctioning of this development without the parallel development of safeguards to ensure the power was not abused. However, if the silence of the Convention is accepted as a justification for avoiding the need for prompt judicial review of arrest decisions where police bail is granted it would mean, in effect, that arbitrary or disproportionate arrest and bail decisions can be made with impunity. If our interpretation is correct, it would be open to the police to bail someone without having charged them provided that the judicial supervision that Article 5(3) requires is satisfied within the time frame tolerated by that Article. ${ }^{144}$ This would have been the de facto position when pre-charge police bail was first enacted in the early part of the twentieth century, but as we have demonstrated, arrest now has a different function within the criminal process.

\section{B. Production before a judge or judicial officer}

A further argument is that the police are acting quasi-judicially when they grant bail, and that this satisfies the requirements of Article 5(3). However, although an officer authorised by law to exercise judicial power, within the terms of Article 5(3), is as the ECtHR observed in Schiesser $v$ Switzerland, not necessarily identical with a judge he "must nevertheless have some of the latter's attributes ... that is to say he must satisfy certain conditions each of which constitutes a guarantee for the person arrested". ${ }^{145}$ The quasi-judicial officer must be independent of the executive and the parties. Moreover, he must discharge the procedural and substantive requirements of Article 5(3). The quasijudicial officer must hear representations from the arrested individual, ${ }^{146}$ and he must decide whether the circumstances of the case justify detention, conditional release or unconditional release. This substantive decision must be undertaken against legal criteria. ${ }^{147}$

A custody officer, who is the officer responsible for making precharge (but not street) bail decisions, is clearly not "an officer authorised by law" within the test set out in Schiesser. Although by the PACE 1984, s. 36(5), a custody officer must not be involved in the investigation of the person in respect of whom a bail decision is to be made, he is of relatively low rank and normally works in the same police station, and for the same police force, as the officer carrying out the investigation. The custody officer's discretion to grant bail is to be exercised

\footnotetext{
144 Although there would still be no automatic judicial oversight of arrest decisions.

145 Schiesser v. Switzerland [1979] ECHR 7710/76, at [32].

146 Winterwerp v. Netherlands [1979] ECHR 6301/73, at [60].

147 Ireland v. United Kingdom [1978] ECHR 5310/71, at [199].
} 
in accordance with guidance produced by the Director of Public Prosecutions, a party to any subsequent criminal proceedings. ${ }^{148}$ The institutional closeness that this regime inevitably creates between the custody officer and the prosecutor hardly enhances the independence of the former. ${ }^{149}$ Furthermore, the custody officer has a conflicting role. ${ }^{150}$ On the one hand he has to act effectively as judge in his own cause, by determining whether the police have sufficient evidence to proceed with a case, and on the other he has to consider whether a suspect should be released. In such circumstances he can hardly be said to be independent of the parties in the manner that Article 5(3) requires. ${ }^{151}$ Research evidence as to the practice of custody officer, as Hucklesby notes, shows that custody officers routinely confirm the decisions and actions of the investigating officers. ${ }^{152}$ As the ECtHR made clear in Salov v Ukraine, ${ }^{153}$ an investigating prosecutor under Ukrainian law is not "an officer authorised by law to exercise judicial power" for the purposes of Article 5(3). That must equally be true of the custody officer in England and Wales. ${ }^{154}$

With regard to street bail the situation is in many ways even more unsatisfactory. The officer making the bail decision is the officer who has carried out the arrest, and the decision will be made away from the police station and normally, literally, in the street. The streets have a different dynamic than police stations. It is a setting in which police officers exercising powers are not only unsupervised but are also in a disproportionately stronger position vis-à-vis the suspect. ${ }^{155}$ Moreover, the constable is not even under the direct supervision of the courts in the case of street bail since, as noted earlier, a suspect who wants to

${ }^{148}$ Although by virtue of PACE 1984, s. 37A(1)(a), this would only apply to bail decisions made under PACE 1984, s. 37(7), s. 37C(2) or s. 37CA(2) and not, for example, to bail under s. 37(2). Custody officers are required to have regard to any such guidance (s. $37 \mathrm{~A}(3)$ ). It would seem that a Crown Prosecutor does not have power to make a bail decision, or to direct a custody officer to make a bail decision, in an individual case, although ss. 37B - 37CA are not completely clear on this point. See Merit v. Ukraine [2004] ECHR 66561/01, at [62]-[63]; and also Niedbala v. Poland [2000] ECHR 27915/95, at [51]-[57].

149 Pantea v. Romania [2003] ECHR 33343/96, at [236]-[239].

150 These conflicting roles are similar to those found in courts martial. See Miller v. UK [2004] ECHR 45825/99, at [29]-[30].

151 Thompson v. United Kingdom [2004] ECHR 36256/97, at [33].

152 A. Hucklesby, "Police Bail and the Use of Conditions" (2001) Criminology and Criminal Justice $441,443$.

153 [2005] ECHR 65518/01. At [58] the Court concluded: "The prosecution authorities not only belong to the executive branch of the State, but they also concurrently perform investigative and prosecution functions in criminal proceedings and are party to those proceedings. The Court therefore reiterates its position as to the status of the prosecutor, who cannot be regarded as an officer authorised by law to exercise judicial power! and rejects the Government's arguments in this respect".

154 Both the police (Police Act 1996) and the Crown Prosecution Service (Prosecution of Offenders Act 1985) are creatures of statute. Both are nominally operationally independent but are subject to the control of the executive (Police Act 1996, s. 36A and Prosecution of Offences Act 1985, ss. 2 and 9).

${ }^{155}$ See A. Sanders and R. Young, Criminal Justice ( $3^{\text {rd }}$ ed, Oxford University Press, 2007) especially chapters 2 and 3 . 
have his bail conditions reviewed must, in the first instance, apply to a custody officer at the designated station and not to a magistrates' court. $^{156}$

\section{BAIL CONDITIONS}

We have argued that the legislative arrangements governing street and pre-charge police bail contravene the requirements of Article 5(3) ECHR. If that argument does not find favour, we argue in this section that conditional street and pre-charge police bail may, nevertheless, amount to a breach of ECHR rights in particular circumstances. Whilst our focus is particularly on Article 5, conditional police bail may raise questions about breach of other Convention rights, particularly the right to private life under Article 8, the right to freedom of expression under Article 10, and the right to freedom of assembly and association under Article 11. The ECtHR has long held that "if a law confers a discretion on a public authority it must indicate the scope of the discretion". ${ }^{157}$ The absence "of any details at all as to the kind of restrictions permitted or their purpose, duration and extent or the arrangements of their review" $" 158$ will not be compatible with the principle of legality. Such unconstrained powers lack the minimum degree of protection against arbitrary interferences with Convention rights. ${ }^{159}$ The principle of legality not only requires that there be a legal basis for the interference with Convention rights, but also that the law has certain qualities. ${ }^{160}$ First, the law must provide sufficient notice as to when and how a public authority can resort to a restrictive measure. Second, the law:

must afford a measure of legal protection against arbitrary interference by public authorities with the rights guaranteed by the Convention ... [I]n matters affecting fundamental rights it would be contrary to the rule of law for legal discretion granted to the executive to be expressed in terms of unfettered power... [C]onsequently, the law must indicate the scope of any such discretion conferred on the competent authorities and the manner of its exercise with sufficient clarity, having regard to the legitimate aim of the measure in question, in order to give the individual adequate protection against arbitrary interference. ${ }^{161}$

\footnotetext{
${ }^{156}$ PACE 1984, s. 30CA. Subsequently the suspect can apply to a magistrates' court under s. 30CB.

157 Herczegfalvy v. Austria [1993] ECHR 10533/83, at [89].

${ }_{158}^{158}$ Note 156 above, at [96].

159 Note 156 above, at [96].

160 "Quality in this sense implies that where a national law authorises deprivation of liberty it must be sufficiently accessible and precise, in order to avoid all risk of arbitrariness": Amuur v. France [1996] ECHR 19776/92, at [50].

161 Vlasov v. Russia [2008] ECHR 78146/01, at [125].
} 
The danger is that unconstrained powers allow arbitrary interferences with Convention rights. Such powers may be used for purposes that are neither necessary, nor within the original purpose. ${ }^{162}$

Pre-charge police bail (both street bail and bail from the police station) with conditions attached could, in certain circumstances, present such problems. For instance, the police might impose restrictions on demonstrators that are, in effect, the same as a bind-over by a magistrates' court. Not surprisingly, for some police officers, "bail conditions are seen as levers of power over defendants ... Conditions might be added to police bail legitimately as ... negotiating mechanisms, for example, in return for favours such as intelligence gathering [or] as summary punishment to be meted out in the relative privacy of the police station on those who otherwise might have been granted unconditional bail". ${ }^{163}$ Moreover, as Choongh has demonstrated, the police use the legal canopy of powers to shield their control of what they consider to be deviant populations. Police powers and the custody suite constitute the criminal justice system for such people; a legal twilight zone. Police bail without charge may amount to a power, par excellence, for disciplining such people since it may be used at a time or in circumstances where there is no intention to charge them, and thus bring them into the legal system proper. ${ }^{164}$ This is not something that sits comfortably with the requirements of the Convention with its avowed prohibition of arbitrary interferences with Convention rights; guarantees that are to be real and effective not theoretic and illusory. ${ }^{165}$

In order to ensure that discretionary powers are exercised appropriately the Convention requires that they are accompanied by effective safeguards. ${ }^{166}$ Such safeguards have a number of benefits. Safeguards can prevent discretionary powers being used in a way that is discriminatory. ${ }^{167}$ Similarly, because a broad discretionary power makes it difficult to know in what circumstances a person may legitimately complain about the exercise of the power, clearly defining the power enables effective ex post facto review and scrutiny. ${ }^{168}$ In turn, that ensures the lawfulness of any interference with Convention rights. If conditions are to be imposed, both in respect of street bail or precharge bail, the officer must consider them "necessary" for one or more

162 Vasileva v. Denmark [2003] ECHR 52792/99.

163 J. Raine and M. Wilson, "Police Bail - Perspectives on the Use, Misuse and Consequences of new Police Power" (1997) 37 British Journal of Criminology 593, 605.

164 S. Choongh, "Policing the Dross - A Social Disciplinary Model of Policing" (1998) 38 British Journal of Criminology 623, 625; A. Hucklesby, "Police Bail and the Use of Conditions" (2001) Criminology and Criminal Justice 441, 444.

165 See for example Artico v. Italy [1980] ECHR 6694/74.

166 Smirnov v. Russia [2005] ECHR 71362/01, at [49]; Gillan v. UK [2010] ECHR 4158/05, at [76]-[87].

167 Papachristou v. City of Jackonsville 405 US 156, 170 (1972).

168 Dawood v. Minister of Immigration [2000] CCT 35/99, at [47] (O’Regan J). 
of the statutory purposes. ${ }^{169}$ Whilst conditions must be necessary for one of these primary purposes the police have a wide discretion to attach ancillary conditions purportedly to support the primary one. ${ }^{170}$ So conditional bail might be viewed as necessary to prevent offending, and primary conditions attached in order to achieve that, but ancillary condition may additionally be imposed to ensure that the primary condition is effective. However, simply because there is a correlation between primary and ancillary conditions it does not mean that the latter are compatible with the ECHR. ${ }^{171}$ The ancillary conditions might have a legitimate aim but that alone does not make them proportionate.

The problem here is that not only are the primary heads of justification for bail broadly defined, for example the prevention of further offending, but also that the discretionary powers to impose ancillary conditions are also expressed in open-ended terms. The latter is exacerbated by the fact that there is also no statutory guidance on how the power to impose conditions is to be exercised, and what conditions might be appropriate or acceptable. The guidance that is available is scattered across various sources such as Home Office circulars ${ }^{172}$ and Association of Chief Police Officers (ACPO) guidance. Arguably, this non-statutory guidance does not satisfy the requirement of legality inherent in the Convention, ${ }^{173}$ and as such cannot be used to justify decisions regarding bail conditions. The absence of proper guidance for a statutory discretionary bail power was held by the European Court in Gatt v Malta to be incompatible with Article 5(1)(b) on the grounds that the unguided exercise of the power could lead to arbitrary and disproportionate results. ${ }^{174}$

Furthermore, with such a wide discretionary power it is not surprising that the police may impose conditions that, in themselves, curtail a range of Convention rights. ${ }^{175}$ Thus it is possible that an individual be made subject to police bail conditions that are sufficiently restrictive of their liberty to amount to a deprivation under Article 5

169 Bail Act 1976, s. 3(6) and PACE 1984, s. 30A(3B) are almost identical in this respect. Conditions may be imposed if they are necessary to secure that the suspect surrenders to custody, does not commit an offence whilst on bail, does not interfere with witnesses or otherwise obstruct the course of justice, or necessary for his own protection or, in the case of a suspect under the age of 17 , for his own welfare or in his own interests.

170 In the same way that magistrates do. See $R$ v. Mansfield Justices, ex parte Sharkey [1985] 1 All ER 193. Hucklesby (note 163 above, at 261) noted that magistrates' courts can impose an infinite variety of bail conditions. This is true of police bail as well, the police enjoying virtually the same powers.

171 See the discussion in the Law Commission, Bail and the Human Rights Act 1998 (Law Com No 269 HC 7, 2001) [9B-15] - [9B-18].

172 For example, Home Office Circulars 61/2002, 61/2003 and 021/2007.

173 Khan v. United Kingdom [2000] ECHR 35394/97, at [25]-[28].

174 Gatt v. Malta [2010] ECHR 28221/08, at [49].

175 We do not know what conditions the police, in general, impose as this information is not collected or, indeed, monitored centrally. 
ECHR. ${ }^{176}$ Curfews, for example, have the potential to infringe Article $5 .{ }^{177}$ A curfew can shade into house arrest, becoming in effect more restrictive than an open prison. ${ }^{178}$ Where someone is subject to a curfew that lasts longer than sixteen hours a day they are in effect imprisoned. ${ }^{179}$ It is interesting, in passing, to contrast the position of suspects on police bail with those on court bail. Where an individual is remanded on bail by a court, the time spent subject to a curfew can be taken into account when discounting any sentence imposed following conviction. ${ }^{180}$ No such considerations apply in the case of police bail.

Where a person is suspected of domestic violence the police may well impose bail conditions that prevent the suspect from staying at his home address or indeed visiting the family home. ${ }^{181}$ There may, of course, be good reasons for such ancillary conditions. However, any such conditions are a serious interference with the right to a home life as guaranteed by Article 8 and should not lightly be imposed on an individual who has not been found guilty of an offence and indeed is presumed to be innocent. Yet the Home Office/ACPO Guidance on the Safer Detention and Handling of Persons in Police Custody states that such conditions should be considered automatically in cases of alleged domestic violence. ${ }^{182}$

There is nothing in domestic law to prevent the police from imposing association restrictions as a form of summary punishment which, as Raine and Wilson argue, is something that is done by magistrates' courts. ${ }^{183}$ For instance, members of the campaign group "Global Rush" were arrested for gluing themselves together in Parliament as a form of protest. Group members were subsequently bailed by the police with the condition that they did not "directly or indirectly" communicate with each other. ${ }^{184}$ Such police bail conditions

${ }^{176}$ For example, many of the Belmarsh detainees were freed on conditional bail following the decision of the House of Lords in $A$ v. Home Secretary [2004] UKHL 56. Those conditions were in effect identical to the control orders later imposed on the terrorist suspects. See C. Walker, "Keeping Control of Terrorists without Losing Control of Constitutionalism” (2006-2007) 59 Stan. L. Rev. $1395,1410$.

${ }^{177}$ Each case inevitably turns on its own facts: "To determine whether a person is deprived of his or her liberty the Court must look upon the actual circumstances of the regime to which he or she was subject, as a matter of law and in fact" (Pekov v. Bulgaria [2006] ECHR 50358/99, at [73]).

178 Secretary of State for the Home Department v. JJ [2007] UKHL 45 [2008] 1 AC 385, [103] (Lord Brown).

${ }^{179}$ Note 177 above, [105], (Lord Brown) and [61] (Lady Hale).

180 CJA 2003 s. 240 A. A "qualifying curfew condition" is defined as "a condition of bail which requires the person granted bail to remain at one or more specified places for a total of not less than 9 hours in any given day". The defendant must be electronically tagged: $R$ v. Barrett [2009] All E.R. (D) 40 (Sep); $R$ v. Girma [2009] EWCA Crim 912, at [95]. For discounts before s. 240A came into force see $R$ v. Glover [2008] EWCA Crim 1782, at [14] (Hughes L.J.).

181 See model conditions in Home Office and ACPO Guidance on the Safer Detention and Handling of Persons in Police Custody (2006), 171.

${ }^{182}$ Note 180 above.

183 Raine and Wilson, note 162 above, pp. 258-259.

${ }^{184}$ Baroness Miller of Chilthorne Domer, Policing and Crime Bill, HC Deb. vol. 713 col. 579 (20 Oct 2009)., and see P. Lewis, "Lawyers to fight bail conditions that 'stifle' climate protests", 
clearly have the potential to interfere unjustifiably with political rights and freedoms guaranteed by Articles 10 and 11 ECHR. Furthermore, the availability of street bail powers means that officers policing unpopular demonstrations now have a new low level discretionary power that effectively enables them to disperse and control demonstrators in a draconian way with little oversight. ${ }^{185}$

\section{Conclusions}

Police powers to impose bail, conditional or unconditional, on people who have not been charged with a criminal offence suffer from considerable and serious procedural deficiencies. The suspect has no, or limited, right to be given information as to why bail or bail conditions are considered to be necessary, and has no right to make any representations regarding either bail or conditions. Even if they are able to make representations, the officer making the decision is under no obligation to take them into account. There are very few limitations on the conditions that can be imposed, and no special provisions for juveniles or other vulnerable suspects. Conditional bail is not limited by reference to the seriousness of the suspected offence, and there is no time limit on the period for which bail can be imposed. Judicial involvement is limited to varying or removing conditions, does not in practice extend to the decision to bail itself, and is available only at the instance of the suspect. As a result, in terms of procedural justice, a suspect who has not been charged with a criminal offence is at a significant disadvantage compared to a person who has.

We have argued that these powers fail to meet the requirements of Article 5 and, in particular, Article 5(3) ECHR. The Convention requires that following arrest a person must promptly be brought before a judge or other judicial officer. Whilst Article 5 does embrace the notion of conditional release, this is only at the instance of a judge or judicial officer. A police officer cannot be a judicial officer for this purpose, and the police are not absolved from the obligation of prompt production by granting them bail. The purpose of the requirement of prompt production is not only so that a decision about release may be made, but also to enable the legality (which would include the proportionality) of the arrest to be judicially reviewed. Even if the provisions do not, per se, breach Convention rights then their use in

The Guardian 3 May 2009, available at www.guardian.co.uk/environment/2009/may/03/climaterush-protesters-bail-challenge. They were also prohibited from being any closer to Parliament than one kilometre.

185 See a discussion of this problem with respect to Terrorism Act 2000, ss. 44 and 45, powers in R. Edwards, "Stop and Search, Terrorism and the Human Rights Deficit" (2008) 37 C.L.W.R. 211, 221-222. In Gillan the ECtHR declined to examine the application under Articles 10 and 11 having held that there was an infringement under Article 8 ECHR. 
particular circumstances may amount to a breach of rights under Articles 8,10 or 11 and, in either case, their use may be discriminatory contrary to Article 14. The prospects of successful challenge in respect of the latter is fundamentally undermined by the failure to require the routine collection of police bail statistics.

It could be legitimate for the police to bail an arrested person who has not been charged provided that the prompt production provisions of Article 5(3) are complied with. In this way police bail could return to its original purpose, namely that of liberating the individual pending imminent judicial process. One way of doing so would be to provide that where bail is granted, whether or not conditional, for a period exceeding four days ${ }^{186}$ the case is automatically referred to a magistrates' court for review. The court would have powers to consider the legality of the arrest (and thus ensure compliance with Article 5(1)(c) and (3)), the need for bail (as opposed to unconditional release), and the necessity of the conditions. In doing so, the court would be required to consider whether both bail, and bail conditions, are proportionate given the seriousness of the offence under investigation. Such a procedure would be more difficult to apply in the case of street bail, but there are strong arguments for abolition of street bail. It appears that the police are not generally well disposed to street bail, especially with conditions, and it is difficult to justify arresting officers having such powers.

As we have demonstrated, police powers to bail persons who have not been charged with a criminal offence are by no means new. However, the development of the police role in the investigation of crime, with the consequence change in the role of arrest, together with the relatively new powers to impose conditions, has substantially altered the nature of these powers. The police now have extensive powers to control and supervise people who have not been found guilty of any offence. Those powers are subject to limited judicial oversight and, in the absence of evidence as to their use, limited public accountability. It is surely time for them to be fundamentally re-assessed.

${ }^{186}$ See Brogan and others v. United Kingdom (1989) 11 EHRR 117. 